\title{
GENOMIC BREEDING VALUES FOR CLAW DISEASES/DISORDERS IN CZECH HOLSTEIN COWS
}

\author{
Ludmila Zavadilová1, Eva Kašná1 ${ }^{1}$ Zuzana Krupová ${ }^{1}$ \\ ${ }^{1}$ Institute of Animal Science, Přátelství 815, 10400 Prague - Uhříněves, Czech Republic \\ To link to this article: https://doi.org/10.11118/actaun201967051245 \\ Received: 12. 8. 2019, Accepted: 18. 9. 2019 \\ To cite this article: ZAVADILOVÁ LUDMILA, KAŠNÁ EVA, KRUPOVÁ ZUZANA. 2019. Genomic Breeding Values \\ for Claw Diseases/Disorders in Czech Holstein Cows. Acta Universitatis Agriculturae et Silviculturae \\ Mendelianae Brunensis, 67(5): 1245-1251.
}

\begin{abstract}
Genomic breeding values (GEBV) were predicted for claw diseases/disorders in Holstein cows. The data sets included 6,498, 6,641 and 16,208 cows for the three groups of analysed disorders. The analysed traits were infectious diseases (ID), including digital and interdigital dermatitis and interdigital phlegmon, and non-infectious diseases (NID), including ulcers, white line disease, horn fissures, and double sole and overall claw disease (OCD), comprising all recorded disorders. Claw diseases/disorders were defined as 0/1 occurrence per lactation. Linear animal models were employed for prediction of conventional breeding values (BV) and genomic breeding values (GEBV), including the random additive genetic effect of animal and the permanent environmental effect of cow and fixed effects of parity, herd, year and month of calving. Both high and intermediate weights (80\% and 50\%, respectively) of genomic information were employed for GEBV50 and GEBV80 prediction. The estimated heritability for ID was 3.47\%, whereas that for NID 4.61\% and for OCD was 2.29\%. Approximate genetic correlations among claw diseases/disorders traits ranged from 19\% (ID x NID) to 81\% (NID x OCD). The correlations between predicted BV and GEBV50 (84-99\%) were higher than those between BV and GEBV80 (70-98\%). Reliability of breeding values was low for each claw disease/disorder (on average, 3.7 to 14.8\%) and increased with the weight of genomic information employed.
\end{abstract}

Keywords: dairy cattle, foot and claw disorders, heritability, genomic breeding values, Holstein breed

\section{INTRODUCTION}

Claw diseases/disorders are possible candidates for improvement by selection due to their negative influence on production, reproduction and culling of cows; the welfare of the animals; and the economic success of farms (Egger-Danner et al., 2013; van der Spek, 2015; Heringstad et al., 2018; Alvergnas et al., 2019). Low incidence of claw diseases/disorders can be accomplished by management practices, but genetic changes in animals by selection are advantageous because positive changes are transmitted between generations. Sufficient genetic variability as a condition of successful genetic selection was confirmed in cases by Buch et al. (2011), Chapinal et al. (2013) and Pérez-Cabal and
Charfeddine (2015). In the Czech Republic, the analysis of genetic parameters has been done by Zavadilová et al. (2018). The economic importance of claw diseases as breeding objectives was analysed by Krupová et al. (2018).

A single-step procedure for genomic evaluation was developed by Misztal et al. (2009), Christensen and Lund (2010) and Legarra and Ducrocq (2012), combining all sources of information on target animals to directly predict genomic breeding values. This procedure directly predicts genomic values through consideration of production records and pedigree databases along with genomic information. Prribyl et al. (2012) tested the single-step procedure for the genetic prediction of production traits in Czech Holstein cattle. 
The aim of this study was to predict genomic breeding values for claw diseases/disorders recorded in the Czech Republic and to compare resulting conventional and genomic breeding values when high and intermediate weights (80\% and 50\%) of genomic information are employed.

\section{MATERIALS AND METHODS}

\section{Data Description and Editing}

The raw data set consists of 49,305 lactations of 40,611 cows with 19,888 diagnoses recorded from 89 farms. Data were obtained by the national cattle health monitoring system "The Diary of Diseases and Medication” (The Diary) (Kašná et al., 2017). In the Czech Republic, this recording system was implemented in August 2018 after a one year trial period. It consists of on-line health recording form for farmers and a simplified key for diagnoses based on ICAR recommendations (ICAR Claw Health Atlas (Egger-Danner et al., 2015)). Records of claw diseases/disorders were gathered during both regular and emergency visits of trimmers to the farms.

The SAS software package, version 9.4 (SAS, 2012) was used to perform data editing and calculation of correlations and basic statistics. Only cows with $75 \%$ or greater Holstein breed were included. Three groups of claw disorders were defined: infectious diseases (ID), including digital and interdigital dermatitis and interdigital phlegmon; noninfectious diseases (NID) including ulcers, white line disease, horn fissures, and double sole; and overall claw disease (OCD). These categories comprised all recorded claw disease and disorders plus lameness.
The incidence of claw diseases/disorders is reported in Tab. I.

For each of the three analysed groups of diseases/ disorders a separate dataset was created because of differences in monitoring of claw disease among herds. For each particular trait, a herd was omitted when the lactation incidence rate (LIR) of the trait was less than $2 \%$.

$$
\begin{aligned}
\operatorname{LIR}(\%)= & \text { number of affected lactations } \times \\
& \times 100 / \text { number of lactations. }
\end{aligned}
$$

The final numbers of herds assigned for analysis was 13 (ID), 14 (NID) and 35 (OCD). The increase in the number of herds selected for analysis of OCD was caused by counting of lameness (26\% of records of OCD) that together with ID and NID records comprised OCD. After editing, the data sets included 6,498, 6,641 and 16,208 cows for the three groups of analysed disorders. The descriptive statistics for the dataset are reported in Tab. II.

\section{Linear Model for Data Analysis}

A univariate linear animal model was employed to estimate heritability and subsequent prediction of breeding values for foot and claw diseases/disorders. The model equation was:

$$
\begin{aligned}
\mathrm{y}_{i j k l m}= & \text { parity }_{i}+\text { herd }_{j}+\text { month-year }_{\mathrm{k}}+ \\
& +\mathrm{pe}_{l}+\mathrm{a}_{m}+\mathrm{e}_{i j k l m},
\end{aligned}
$$

where $\mathrm{y}_{i j k l m}$ is the analysed trait: ID, NID, OCD defined as 0/1 occurrence per lactation, in period from calving to 305 days in milk (DIM); parity is the effect of parity class $i$ (5 levels, first, second, third, fourth, five and higher parity); herd is the effect of

I: The number of claw diseases/disorders, total and most frequent diseases/disorders (Holstein cows)

\begin{tabular}{lrccc}
\hline \multicolumn{1}{c}{ Trait/Diagnosis } & No. of records & No. of cows & Ratio of cow with 1 record & $\begin{array}{c}\text { Maximum no. } \\
\text { of records per cow }\end{array}$ \\
\hline ID in total & 1101 & 902 & $83 \%$ & 6 \\
Digital/interdigital dermatitis & 581 & 464 & $81 \%$ & 6 \\
Interdigital phlegmon & 465 & 411 & $89 \%$ & 5 \\
NID in total & 1678 & 999 & $67 \%$ & 11 \\
Ulcers & 1600 & 975 & $70 \%$ & 11 \\
OCD in total & 4110 & 2561 & $71 \%$ & 15 \\
Lameness & 1087 & 811 & $83 \%$ & 6 \\
\hline
\end{tabular}

II: The descriptive statistics for the datasets

\begin{tabular}{lcccc}
\hline \multicolumn{1}{c}{ Trait } & No. of cows with data & No. of lactations & LIR* & No. of sires of cows with data \\
\hline Infectious diseases & 6498 & 7272 & $8.24 \%$ & 810 \\
Non-infectious disorders & 6641 & 7481 & $11.76 \%$ & 859 \\
Overall claw disorders & 16208 & 18385 & $10.00 \%$ & 1641 \\
\hline
\end{tabular}

*lactation incidence rate 
herd $j$ (13 (ID), 14 (NID) and 35 (OCD) levels); monthyear $_{k}$ is the effect of calving month-year $k$ (8 levels); $\mathrm{pe}_{l}$ is the random permanent environmental effect on a cow; $\mathrm{a}_{m}$ is the random additive genetic effect of cow $m$; and $\mathrm{e}_{i j k m}$ is the random residual effect.

The model equation was the same for each foot and claw diseases/disorders trait, for both conventional as well as genomic prediction.

For prediction of genomic breeding values, a single-step procedure was applied (Aguilar et al., 2010, Christensen and Lund, 2010). A genomic relationship matrix $G$ was calculated according to deviations from the averages of observed allele frequencies and standardized using division by the average value of the diagonal of $\mathrm{G}$, so that average of diagonal elements $=1$ (Forni et al., 2011), and transformed so that the elements of an additive pedigree relationship matrix for genotyped animals A22 and elements of $G$ have the same average (Vitezica et al., 2011). Two weights, 80\% and 50\%, of the genomic relationship were employed. Resulting predictions included conventional breeding values (BV), genomic breeding values with 50\% genomic relationship included (GEBV50) and those with $80 \%$ genomic relationship included (GEBV80). The relative breeding values in \% for BV, GEBV50 and GEBV80 were calculated using a reference level derived from sires born in 2010 (mean) and SD = 12 . Higher relative breeding values mean a higher required value for a trait, for example, higher resistance to particular claw disease/disorder. The reliability of each breeding value was calculated using the standard error of prediction and additive variance for particular traits.

The pedigree file contained 25,446 (ID), 36,092 (NID), and 49,700 (OCD) records (4 generations). The genotyped animals were chosen according to pedigree. A detailed account of the allocation of genotyped animals is presented in Tab. III.

The genotypic data were edited both by animal and by loci. Animals with genotype call rates < 95\% were excluded from further evaluation. SNPs were discarded if more than 5\% of SNP calls were missing. The procedure used for selecting SNPs was described by Přibyl et al. (2012). The Illumina BovineSNP50 BeadChip V2 (Illumina Inc., San Diego, USA) was used for preparation of a genomic relationship matrix (G). Initial no. of SNP 54609. The effective no. of SNP was 39537.

Data were analysed using the DMU package (Madsen and Jensen, 2010). Genetic correlations between traits were approximated using correlations between predicted breeding values using Proc corr in Software packages SAS, version 9.4 (2012, SAS).

\section{RESULTS AND DISCUSSION}

\section{Monitoring of Claw Diseases/Disorders}

Because of the relatively short period of data collection (8 months) the database of health traits was small. There were substantial differences between farms in their approaches to monitoring herd health. Omitting herds with low LIR, we obtained our data from farms that employ regular health monitoring. The ID trait was mostly represented by dermatitis and necrobacillosis and NID by ulcers (see Tab. I). A sizeable proportion of OCD records (26\%) were included due to lameness (see Tab. I). Lameness is very general disorder with a number of different causes. It is an indicator of claw and leg problems and is a reasonably proper part of OCD. We conclude that such diagnoses as lameness, dermatitis digitalis and interdigitalis, necrobacillosis and ulcers are most important for the genetic evaluation of health traits in the Czech Republic. Pérez-Cabal and Charfeddine (2015) stated that six infectious and non-infectious claw disorders are monitored in Spanish Holstein cows: dermatitis, sole ulcer, white line disease, interdigital hyperplasia, necrobacillosis, and chronic laminitis, and that this same grouping of claw diseases/ disorders according their causes was used by van der Spek (2015).

\section{Lactation Incidence Rates for Claw Diseases/Disorders}

LIR were similar for each analysed trait (ID 8.24\%, NID $11.76 \%$, and OCD $10.00 \%$.) This is less than the 40 to $70 \%$ reported in recent studies (Sogstad et al., 2005; Buch et al., 2011; Chapinal et al., 2013; van der Spek, 2015). In Czech Holsteins, Krpálková et al. (2019) reported LIRs greater than 50\%. In our study, the low values are probably caused by the short period of monitoring, low number of farms involved and inconsistency of recording among farms. Zavadilová et al. (2018) reported higher LIRs of $28.61 \%$ for ID, $27.15 \%$ for NID and $52.56 \%$ for overall claw diseases. Both Krpálková et al. (2019) and Zavadilová et al. (2018) analysed data from the same source, different from the data sources used in the present study.

III: Number of genotyped animals

\begin{tabular}{lccc}
\hline \multicolumn{1}{c}{ Trait } & No. of sires & No. of females & No. of cows with data \\
\hline Infectious disease & 1444 & 507 & 391 \\
Non-infectious disorders & 1602 & 552 & 439 \\
Overall claw disorders & 1984 & 833 & 626 \\
\hline
\end{tabular}




\section{Variance and Heritability for Claw Diseases/Disorders}

The estimated variances and heritabilities for claw disorders are presented in Tab. IV. Heritability for INF was 3.47\%, whereas those for NID and OCD were $4.61 \%$ and $2.29 \%$, respectively.

These estimates are in agreement with the literature but lower than those estimated by Zavadilová et al. (2018) for Czech Holsteins. Buch et al. (2011) reported heritabilities between 3 and $5 \%$ for particular diseases. Heritability estimates by Chapinal et al., (2013) were 9.2\% for infectious diseases and $4.5 \%$ for non-infectious diseases. Using a linear model, Pérez-Cabal and Charfeddine (2015) estimated heritability at 5\% for overall claw diseases. Zavadilová et al. (2018) calculated heritabilities of $13.84 \%$ for overall claw diseases/ disorders, $12.64 \%$ for non-infectious disorders and $9.83 \%$ for infectious diseases. In this study, the low values of heritability can be explained by the narrow extent of the dataset and the short time of monitoring for claw diseases/disorders. Estimates of heritability should rise both in percentage value and statistical significance in proportion to increases in the number of monitored herds and with provision of an equal chance for every cow to be monitored during its entire period of lactation.

\section{Breeding Values and their Reliability}

The descriptive statistics for breeding values and their reliabilities are presented in Tabs. V, VI and VII.

The impact of genomic information was evident, especially with regards to reliability of breeding values for each analysed trait. For each claw disease/disorder, reliability increased with the amount of genomic information employed. Because this suggestion holds for each trait as well as each group of animals presented in Tabs. V, VI and VII we assumed that the main reason for this phenomenon was the genomic information. The increase in reliability is proportional to the amount of genomic information employed. The increase in reliability due to the amount of genomic information is usually explained by increased accuracy of the relationship matrix. Between analysed claw diseases, the greatest increase occurred for noninfectious disease (8.3\% for cows with records). This is less than results typically found in the literature (Aquilar et al., 2010; Přibyl et al., 2012).

Other than this trend in reliability, there is no systematic change in means, standard errors, maximums and minimums for breeding values that could be correlated with increases in genomic information. For infectious claw disease the means for breeding values and their SDs decreased, for non-infectious claw diseases/disorders the means

IV: Estimates of heritability for claw diseases/disorders

\begin{tabular}{lccc}
\hline & Infectious disease & Non-infectious disorders & Overall claw disorders \\
\hline Additive variance & $0.0025 \pm 0.0011^{*}$ & $0.0035 \pm 0.0012^{* *}$ & $0.0019 \pm 0.0006^{* *}$ \\
Variance of permanent environment & $0.0119 \pm 0.0030^{* *}$ & $0.0010 \pm 0.0030$ & $0.0023 \pm 0.0021^{*}$ \\
Residual variance & $0.0580 \pm 0.0029^{* *}$ & $0.0714 \pm 0.0031^{* *}$ & $0.0775 \pm 0.0022^{* *}$ \\
Heritability & $3.47 \% \pm 0.068^{* *}$ & $4.61 \% \pm 0.073^{* *}$ & $2.29 \% \pm 0.037^{* *}$ \\
\hline
\end{tabular}

$* \mathrm{P}<0.05$

$* * \mathrm{P}<0.01$

V: Descriptive statistics for relative breeding values (\%) for infectious claw disease

\begin{tabular}{|c|c|c|c|c|c|c|c|}
\hline Breeding values & No. & Mean & SD & Min. & Max. & Mean of reliability & SD of reliability \\
\hline \multicolumn{8}{|c|}{ Cows with records } \\
\hline Conventional & 6498 & 101.3 & 14.34 & 28.1 & 147.9 & 11.3 & 3.79 \\
\hline Genomic 50\% & 6498 & 99.5 & 13.67 & 28.8 & 142.9 & 12.4 & 4.04 \\
\hline Genomic $80 \%$ & 6498 & 98.8 & 13.72 & 27.8 & 141.2 & 13.2 & 4.19 \\
\hline \multicolumn{8}{|c|}{ Genotyped sires } \\
\hline Conventional & 1444 & 101.3 & 11.08 & 29.5 & 157.6 & 7.6 & 9.59 \\
\hline Genomic 50\% & 1444 & 99.5 & 10.84 & 29.7 & 155.3 & 7.4 & 10.75 \\
\hline Genomic $80 \%$ & 1444 & 98.7 & 11.47 & 28.4 & 155.5 & 8.4 & 11.47 \\
\hline \multicolumn{8}{|c|}{ Genotyped cows and heifers } \\
\hline Conventional & 507 & 102.7 & 13.41 & 50.0 & 141.4 & 9.1 & 4.47 \\
\hline Genomic 50\% & 507 & 100.7 & 12.48 & 52.2 & 134.6 & 10.5 & 5.49 \\
\hline Genomic $80 \%$ & 507 & 99.8 & 12.65 & 52.7 & 134.0 & 12.0 & 6.14 \\
\hline
\end{tabular}


VI: Descriptive statistics for relative breeding values (\%) for non-infectious claw disease

\begin{tabular}{lccccccc}
\hline \multicolumn{1}{c}{ Breeding values } & No. & Mean & SD & Min. & Max. & Mean of reliability & SD of reliability \\
\hline Conventional & 6641 & 94.3 & 19.83 & 8.7 & 177.3 & 6.5 & 3.66 \\
Genomic 50\% & 6641 & 95.2 & 19.13 & 14.0 & 174.8 & 12.0 & 3.91 \\
Genomic 80\% & 6641 & 96.1 & 19.39 & 14.6 & 176.0 & 14.8 & 4.14 \\
\hline & \multicolumn{7}{c}{ Genotyped sires } \\
\hline Conventional & 1602 & 93.5 & 17.33 & -11.2 & 188.8 & 3.7 & 10.00 \\
Genomic 50\% & 1602 & 94.6 & 17.22 & -2.5 & 188.6 & 6.1 & 11.69 \\
Genomic 80\% & 1602 & 95.4 & 17.96 & 0.4 & 191.1 & 8.4 & 12.92 \\
\hline Conventional & \multicolumn{7}{c}{ Genotyped cows and heifers } \\
Genomic 50\% & 552 & 96.2 & 13.72 & 47.7 & 132.7 & 4.3 & 4.56 \\
Genomic 80\% & 552 & 96.7 & 13.51 & 48.9 & 132.2 & 9.5 & 5.73 \\
\hline
\end{tabular}

VII: Descriptive statistics for relative breeding values (\%) for overall claw disorders

\begin{tabular}{lccccccc}
\hline \multicolumn{1}{c}{ Breeding values } & No. & Mean & SD & Min. & Max. & Mean of reliability & SD of reliability \\
\hline \multicolumn{7}{c}{ Cows with records } \\
\hline Conventional & 16208 & 104.1 & 12.26 & 39.6 & 153.5 & 10.9 & 3.97 \\
Genomic 50\% & 16208 & 100.6 & 11.99 & 40.3 & 151.8 & 11.5 & 4.11 \\
Genomic 80\% & 16208 & 99.1 & 12.16 & 40.2 & 151.8 & 12.2 & 4.22 \\
\hline \multicolumn{7}{c}{ Genotyped sires } \\
\hline Conventional & 1876 & 103.1 & 11.37 & 35.2 & 159.3 & 9.3 & 10.54 \\
Genomic 50\% & 1876 & 98.5 & 12.28 & 36.4 & 155.8 & 9.8 & 11.51 \\
Genomic 80\% & 1876 & 96.5 & 13.41 & 36.7 & 153.8 & 11.6 & 12.27 \\
\hline Conventional & 803 & 104.3 & 11.53 & 58.2 & 138.3 & 9.3 & 4.83 \\
Genomic 50\% & 803 & 99.9 & 11.52 & 56.7 & 136.5 & 10.5 & 5.70 \\
Genomic 80\% & 803 & 97.9 & 12.21 & 55.4 & 135.8 & 12.3 & 6.26 \\
\hline
\end{tabular}

for breeding values increased but their SDs did not change, and for overall claw diseases the means for breeding values decreased and their SDs increased with amount of genomic information employed; therefore, genomic information influenced each trait according to genetic control of that trait. Differences between infectious and non-infectious claw diseases are obvious. Dissimilarity in OCDs is caused by inclusion of lameness (26\%), a trait that is constituted apart from infectious and noninfectious diseases due to it being a very general trait with many causes.

The correlations between BV and GEBV50 (8499\%) were higher than those between BV and GEBV80 (70-98\%) as seen in Tab. VIII. Although the majority of correlations between these types of genomic breeding values are 99\% the correlations to conventional breeding values are different. Generally, GEBV80 showed lower correlations with BV then GEBV50. In any case, if the number of animals in a group is high (Tab. VIII, Cows with records) then the correlations between BV and genomic breeding values approach 99\%.

\section{Genetic Correlations between Claw Diseases/Disorders}

The approximate genetic correlations among claw health traits ranged from 19\% (ID x NID) to $81 \%$ (NID x OCD), see Tab. IX. Those between infectious and non-infectious claw diseases were low especially based on the breeding values of sires (from 19\% to 26\%). This is in agreement with the literature when genetic correlations between those traits were estimated directly by multi trait linear models. Genetic correlations between infectious claw diseases and non-infectious disorders were lower than 23\% (Buch et al., 2010). A low genetic correlation between infectious diseases and horn lesions (8\%) was reported by Chapinal et al. (2013). Zavadilová et al. (2018) estimated 18\%. 
VIII: Correlations between conventional breeding values (BV) and genomic breeding values with 50\% (GEBV50) or with 80\% (GEBV80) of genomic information employed for analysed claw diseases/disorders

\begin{tabular}{|c|c|c|c|c|c|}
\hline & & No. & $\begin{array}{c}\text { BV x GEBV50 } \\
(\%)\end{array}$ & $\begin{array}{c}\text { BV x GEBV80 } \\
(\%)\end{array}$ & $\begin{array}{c}\text { GEBV50 x GEBV80 } \\
(\%)\end{array}$ \\
\hline \multirow{3}{*}{ Infectious disease } & Cows with records & 6498 & 99 & 98 & 99 \\
\hline & Genotyped sires & 1444 & 94 & 87 & 98 \\
\hline & Genotyped cows and heifers & 507 & 96 & 91 & 99 \\
\hline \multirow{3}{*}{ Non-infectious disease } & Cows with records & 6641 & 99 & 98 & 99 \\
\hline & Genotyped sires & 1602 & 97 & 93 & 99 \\
\hline & Genotyped cows and heifers & 552 & 95 & 88 & 99 \\
\hline \multirow{4}{*}{ Overall claw disorders } & Cows with records & 16208 & 98 & 95 & 99 \\
\hline & Genotyped sires & 1876 & 91 & 83 & 98 \\
\hline & Genotyped cows and heifers & 803 & 94 & 86 & 98 \\
\hline & Genotyped heifers & 177 & 84 & 70 & 98 \\
\hline
\end{tabular}

IX: Approximation of genetic correlations between analysed claw diseases/disorders using correlations between predicted breeding values

\begin{tabular}{lccccc}
\hline & Breeding value & No. & $\begin{array}{c}\text { ID x OCD } \\
\text { (\%) }\end{array}$ & $\begin{array}{c}\text { NID x OCD } \\
(\%)\end{array}$ & $\begin{array}{c}\text { ID x NID } \\
\text { (\%) }\end{array}$ \\
\hline \multirow{3}{*}{ Sires } & Conventional & 292 & 48 & 66 & 29 \\
& Genomic 50\% & 422 & 49 & 71 & 27 \\
\hline \multirow{3}{*}{ Cows and heifers } & Genomic 80\% & 498 & 48 & 63 & 19 \\
\hline & Conventional & 896 & 66 & 81 & 46 \\
& Genomic 50\% & 2470 & 61 & 81 & 40 \\
\hline
\end{tabular}

\section{CONCLUSION}

Although our heritability estimates were low, claw health traits showed enough genetic variance to hopefully allow genetic selection of Holsteins cows for high susceptibility to claw disease/disorders. The estimates of breeding values will benefit from utilization of genomic information especially in single-step genomic evaluation.

\section{Acknowledgements}

The work was supported by the project of the National Agency for Agricultural Research QK1810253 and the institutional support MZE-RO0718 of the Ministry of Agriculture of the Czech Republic.

\section{REFERENCES}

AGUILAR, I., MISZTAL, I., JOHNSON, D., LEGARRA, A., TSURUTA, S. and LAWLOR, T. 2010. A unified approach to utilize phenotypic, full pedigree, and genomic information for genetic evaluation of Holstein final score. J. Dairy Sci., 93(2): 743-752.

ALVERGNAS, M., STRABEL, T., RZEWUSKA, K. and SELL-KUBIAK, E. 2019. Claw disorders in dairy cattle: Effects on production, welfare and farm economics with possible prevention methods. Livestock Science, 222(4): 54-64.

BUCH, L. H., SØRENSEN, A. C., LASSEN, J., BERG, P., ERIKSSON, J.-Å., JAKOBSEN, J. H. and SøRENSEN, M. K. 2011. Hygiene-related and feed-related hoof diseases show different patterns of genetic correlations to clinical mastitis and female fertility. J. Dairy Sci., 94(3): 1540-1551.

CHAPINAL, N., KOECK, A., SEWALEM, A., KELTON, D. F., MASON, S., CRAMER, G. and MIGLIOR, F. 2013. Genetic parameters for hoof lesions and their relationship with feet and leg traits in Canadian Holstein cows. J. Dairy Sci., 96(4): 2596-2604. 
CHARFEDDINE, N. and PÉREZ-CABAL, M. A. 2017. Effect of claw disorders on milk production, fertility, and longevity, and their economic impact in Spanish Holstein cows. J. Dairy Sci. 100(1): 1-13.

CHRISTENSEN, O. F. and LUND, M. S. 201 Genomic prediction when some animals are not genotyped. Genetics Selection Evolution, 42: 2.

EGGER-DANNER, C., HANSEN, O. K., STOCK, K., PRYCE, J. E., COLE, J., GENGLER, N. and HERINGSTAD, B. (Eds.). 2013. Challenges and benefits of health data recording in the context of food chain quality, management and breeding: Proceedings of the ICAR Conference. ICAR Technical Series, No. 17.

EGGER-DANNER, C., NIELSEN, P., FIEDLER, A., MÜLlER, A., FJELDAAS, T., DÖPFER, D., DANIEL, V., BERGSTEN, C., CRAMER, G., CHRISTEN, A.-M., STOCK, K. F., THOMAS, G., HOLZHAUER, M., STEINER, A., CLARKE, J., CAPION, N., CHARFEDDINE, N., PRYCE, J. E., OAKES, E., BURGSTALLER, J., HERINGSTAD, B., ØDEGÅD, C., KOFLER, J., EGGER, F. and Cole, J. B. 2015. ICAR claw health atlas. ICAR Technical Series. No. 18. Rome, Italy: ICAR.

FORNI, S., AGUILAR, I. and MISZTAL, I. 2011. Different genomic relationship matrices for single-step analysis using phenotypic, pedigree and genomic information. Genetics Selection Evolution, 43: 1.

HERINGSTAD, B., EGGER-DANNER, C., CHARFEDDINE, N., PRYCE, J. E., STOCK, K. F., KOFLER, J., SOGSTAD, A. M., HOLZHAUER, M., FIEDLER, A., MÜLLER, K., NIELSEN, P., THOMAS, G., GENGLER, N., DE JONG, D., ØDEGÅRD, C., MALCHIODI, F., MIGLIOR, F., ALSAAOD, M. and COLE, J. B. 2018. Invited Review: Genetics and claw health: opportunities to enhance claw health by genetic selection. J. Dairy Sci., 101(6): 4801-4821.

KAŠNÁ, E., ZAVADILOVÁ, L., KRUPOVÁ, Z., ŠLOSÁRKOVÁ, S., FLEISCHER, P. and LIPOVSKÝ, D. 2017. National dairy cattle health recording in the Czech Republic. In: EAAP - 68 $8^{\text {th }}$ Annual Meeting. Tallinn 2017. Wageningen: Wageningen Academic Publishers.

KRPÁLKOVÁ, L., CABRERA, V. E., ZAVADILOVÁ, L. and ŠTÍPKOVÁ, M. 2019 The importance of hoof health in dairy production. Czech Journal of Animal Science, 64(3): 107-117.

KRUPOVÁ, Z., WOLFOVÁ, M., KRUPA, E., PŘIBYL, J. and ZAVADILOVÁ, L. 2018. Claw health and feed efficiency as new selection criteria in the Czech Holstein cattle. Czech Journal of Animal Science, 63(10): 408-418.

LEGARRA, A. and DUCROCQ, V. 2012. Computation strategies for national integration of phenotypic, genomic, and pedigree data in a single-step best linear unbiased prediction. J. Dairy Sci., 95(8): 4629-4654.

MADSEN, P. and JENSEN, J. 2001. DMU - a package for analysing multivariate mixed models. Version 6, release 5. [Program]. Aarhus University, Foulum, Denmark. Available at: http://dmu.agrsci.dk [Accessed: 2011, June 1].

MISZTAL, I., LEGARRA, A. and AGUILAR, I. 2009. Computing procedures for genetic evaluation including phenotypic, full pedigree, and genomic information. J. Dairy Sci., 92(9): 4648-4655.

PÉREZ-CABAL, M. A. and CHARFEDDINE, N. 2015. Models for genetic evaluations of claw health traits in Spanish dairy cattle. J. Dairy Sci., 98(11): 8186-8194.

PŘIBYL, J., HAMAN, J., KOTT, T., PŘIBYLOVÁ, J., ŠIMEČKOVÁ, M., VOSTRÝ, L., ZAVADILOVÁ, L., ČERMÁK, V., RŮŽIČKA, Z., ŠPLÍCHAL, J., VERNER, M., MOTYČKA, J. and VONDRÁŠEK, L. 2012. Single-step prediction of genomic breeding value in a small dairy cattle population with strong import of foreign genes. Czech Journal of Animal Science, 57(4): 151-159.

SAS. 2012. Release 9.4 (TS1M1) of the SAS ${ }^{\circledR}$ System for Microsoft ${ }^{\circledR}$ Windows ${ }^{\circledR}$. Cary, USA: SAS Institute.

SOGSTAD, Å., FJELDAAS, T., ØSTERÅS, O. and FORSHELL, K. P. 2005. Prevalence of claw lesions in Norwegian dairy cattle housed in tie stalls and free stalls. Prev. Vet. Med., 70(3-4): 191-209.

VAN DER SPEK, D. 2015. Genetic Background of Claw Health in Dairy Cattle. Wageningen: Wageningen University.

VITEZICA, Z. G., AGUILAR, I., MISZTAL, I. and LEGARRA, A. 2011. Bias in genomic predictions for populations under selection. Genetic Research, 93(5): 357-366.

ZAVADILOVÁ, L., KRUPA, E., KAŠNÁ, E., FLEISCHER, P. and ŠTÍPKOVÁ, M. 2018. Analysis of foot and claw diseases/disorders in Czech Holstein cows. Acta Fytotechnica et Zootechnica, 21(4): 194-196. 